\title{
Steroid Metabolism Gene
}

National Cancer Institute

\section{Source}

National Cancer Institute. Steroid Metabolism Gene. NCI Thesaurus. Code C94606.

A gene that is involved in the synthesis, modification or catabolism of steroids. 